No 4078

Studia nad Autorytaryzmem i Totalitaryzmem 43, nr 4 Wrocław 2021

https://doi.org/10.19195/2300-7249.43.4.11

\author{
ELWIRA MARSZAŁKOWSKA-KRZEŚ \\ ORCID: 0000-0003-3276-4438 \\ Uniwersytet Wrocławski \\ elwira.marszalkowska-krzes@uwr.edu.pl
}

\title{
Autorytarne formy władzy a realizacja prawa do cywilnoprawnej ochrony prawnoprocesowej przez obywateli w okresie PRL
}

Słowa kluczowe: autorytaryzm państwa, postępowanie cywilne, socjalizm, PRL.

\author{
AUTHORITARIAN FORMS OF POWER AND THE REALISATION OF THE RIGHT \\ TO CIVIL LEGAL PROTECTION BY CITIZENS IN THE POLISH PEOPLE'S REPUBLIC
}

\begin{abstract}
The study describes the functions of civil procedure as a legal instrument from the times of the socialist authoritarian state of the People's Republic of Poland. The positions expressed in the doctrine regarding the purpose and principles of conducting civil proceedings, regulated in the Act of 16 November 1964, Code of Civil Procedure, which was adopted during the authoritarian power of the dominant political party of the Polish United Workers' Party, were presented. Provisions of procedural law, dating back to the authoritarian rule of democratic socialism in the People's Republic of Poland, were intended to provide protection for the socialized economy and to enable the state to control civil-law relations. Civil proceedings were intended to guarantee the possibility of protecting not only the rights of the individual, but also, or rather first and foremost, of the units of the socialized economy, as well as of the disputes that might arise in connection with relations between the state and its citizens, and between citizens. This principle required the authorities conducting civil proceedings to ensure adequate legal and procedural protection in the event that a party or participant in the proceedings was a unit of the socialized economy. Civil proceedings in which the court, within its powers, could interfere with the legal sphere of an individual in connection with the conferral of discretionary power, was another legal tool and instrument allowing the state to influence private-law relations. In addition, the authoritarianism of the state power at that time was also manifested in this.
\end{abstract}

Keywords: state authoritarianism, civil proceedings, socialism, PRL. 
W momencie wejścia w życie ustawy z dnia 16 listopada 1964 roku - Kodeks postępowania cywilnego ${ }^{1}$ obowiązywał ustrój socjalistyczny, który opierał się na społecznej własności środków produkcji, co wymagało szczególnych regulacji prawnoprocesowych związanych z zapewnieniem ochrony prawnoprocesowej. Polska z okresu socjalistycznego określana jest jako „Polska Rzeczpospolita Ludowa (w skrócie PRL) - autorytarne państwo w Europie Środkowej istniejące w latach 1944-1989 (oficjalnie od 1952 roku). Formalnie niepodległe, w praktyce częściowo zależne od ZSRR"2. W związku z tym warto opisać w aspekcie historycznoprawnym, jakie funkcje pełniło wówczas postępowanie cywilne, stanowiące jeden z instrumentów prawnych z czasów socjalistycznego autorytarnego państwa PRL.

W opracowaniu przedstawiono stanowiska wyrażane ówcześnie $\mathrm{w}$ doktrynie odnośnie do celu oraz zasad prowadzenia postępowań cywilnych, uregulowanych w przepisach kodeksu postępowania cywilnego. Przedmiotowa ustawa została uchwalona w okresie autorytarnej władzy dominującej partii politycznej — PZPR.

Przepisy prawa procesowego z czasów autorytarnej władzy państwowej socjalizmu demokratycznego miały zapewniać ochronę jednostkom gospodarki uspołecznionej i umożliwiać państwu kontrolę nad stosunkami cywilnoprawnymi. Postępowanie cywilne, w którym sąd w ramach posiadanych uprawnień mógłby ingerować $\mathrm{w}$ sferę prawną jednostki w związku z przyznaniem dyskrecjonalnej władzy stanowiło kolejne narzędzie i instrument prawny pozwalający na wpływ państwa na stosunki prywatnoprawne. W tym przejawiał się także autorytaryzm ówczesnej władzy państwowej.

W doktrynie po uchwaleniu kodeksu postępowania cywilnego wyrażano stanowisko, że

W ustroju Polskiej Rzeczypospolitej Ludowej postępowanie cywilne służy przede wszystkim realizacji zasady praworządności, demokratyzmu socjalistycznego, ochronie własności społecznej i ochronie praw obywateli, zagwarantowanych przez porządek prawny państwa socjalistycznego ${ }^{3}$.

Prowadzenie postępowania cywilnego wiąże się z rozpoznawaniem przez sądy spraw cywilnych, których ustrój i struktury określają przepisy ustrojowe organów prowadzących postępowanie cywilne ${ }^{4}$. Jak podkreślano wówczas $\mathrm{w}$ literaturze, funkcja postępowania cywilnego, stanowiąca jedną z zasadniczych funkcji państwa, polega na zapewnieniu ochrony interesów społecznych i indywidualnych w zakresie stosunków cywilnych, rodzinnych i pracy, zgodnie z wolą klasy rządzącej, przez konkretyzowanie i przymusowe urzeczywistnianie obowiązujących w tym zakresie norm prawnych ${ }^{5}$.

1 Dz.U. z 1964 r. Nr 43, poz. 296 (dalej: k.p.c. z 1964 roku).

2 Polska Rzeczpospolita Ludowa, https://historia.fandom.com/pl/wiki/Polska_Rzeczpospolita_ Ludowa (dostęp: 1.12.2021).

3 W. Siedlecki, Postepowanie cywilne. Zarys wyktadu, Warszawa 1977, s. 12.

4 Por. S. Włodyka, Ustrój organów ochrony prawnej, Warszawa 1975, s. 46 n.

5 W. Berutowicz, Funkcja postepowania cywilnego w Polsce Ludowej, [w:] Wstęp do systemu prawa procesowego cywilnego. Zbiór studiów, red. J. Jodłowski, Wrocław-Warszawa-Kraków-Gdańsk 1974, s. 7. 
Postępowanie cywilne miało nie tylko gwarantować możliwość ochrony praw jednostki, ale też jednostek gospodarki uspołecznionej oraz rozstrzygać spory, jakie mogły powstać w związku ze stosunkami w relacjach państwo-obywatel oraz pomiędzy obywatelami. Podkreślano wówczas w literaturze, że wskutek wejścia $\mathrm{w}$ życie kodeksu postępowania cywilnego przedmiotem rozpoznawania i rozstrzygania spraw w socjalistycznym postępowaniu cywilnym interes jednostki i państwa jest chroniony

równocześnie i równolegle, albowiem ochrona jednego nie wyklucza ochrony drugiego, a przeciwnie - ochrona każdego z nich warunkuje ochronę drugiego. Ta współzależność interesu indywidualnego i społecznego determinuje treść i kierunek funkcji postępowania cywilnego w społeczeństwie socjalistycznym ${ }^{6}$.

Wskazana regulacja odnośnie do zakresu i treści funkcji postępowania cywilnego następowała stopniowo; jak wskazywano,

w miarę jak krzepła władza radziecka w ZSRR, w życiu społecznym kształtowały się stosunki socjalistyczne, niosące ze sobą nowe potrzeby w zakresie wymiaru sprawiedliwości. Dał temu wyraz W.I. Lenin w znanym liście do ówczesnego komisarza sprawiedliwości D. Kurskiego, postulując, aby rozszerzyć wpływ państwa na stosunki prywatnoprawne i nie pomijać żadnej okazji do rozszerzenia możliwości ingerencji państwa w stosunki cywilnoprawne ${ }^{7}$.

Przywołany cytat jednoznacznie obrazuje, jaką funkcję miało pełnić postępowanie cywilne w okresie socjalistycznego państwa polskiego. Jego zasadniczym celem nie było zatem zagwarantowanie jednostce tak zwanego prawa skargi. W tamtym okresie rola sądu, sprowadzająca się do oceny stanu faktycznego sprawy w celu rozpoznania i rozstrzygnięcia o prawach strony inicjującej wszczęcie postępowania pod kątem zasadności jej roszczenia lub prawa, postrzegana była jako cecha procesu z czasu burżuazyjnego. W okresie socjalistycznym uznano, że trzeba wzmocnić rolę sądu i przyznać mu możliwość władczego ingerowania w sferę dyspozycyjności stron, zarówno w aspekcie procesowym, jak i materialnym. Postępowanie cywilne, w którym sąd w ramach posiadanych uprawnień mógłby ingerować $\mathrm{w}$ sferę prawną jednostki w związku z przyznaniem dyskrecjonalnej władzy, mogło stanowić kolejne narzędzie i instrument prawny pozwalający na wpływ państwa na stosunki prywatnoprawne. Zwiększanie uprawnień władczych organów orzeczniczych, w tym możliwość stosowania środków przymusu państwowego, w znaczny sposób ogranicza bowiem prawa podmiotów, w stosunku do których prowadzone jest postępowanie.

Należy podkreślić, że przyznanie uprawnienia organom ścigania (prokuratorowi) wszczęcia, ale i prowadzenia postepowania cywilnego z urzędu stanowi właśnie przejaw możliwości ingerencji państwa w sferę stosunków cywilnoprawnych. Polski ustawodawca, dokonując kodyfikacji postępowania cywilnego, wzorował się na konstrukcjach stosowanych w radzieckim wymiarze sprawiedliwości.

6 W. Broniewicz, Postępowanie cywilne, Warszawa 1978, s. 70.

7 Ibidem. 
W doktrynie politycznoprawnej prezentowano stanowiska w poszczególnych republikach związkowych ZSRR, że kodeksy postępowania cywilnego mają służyć ochronie społecznego i państwowego ustroju ZSRR, a także socjalistycznego systemu gospodarowania, opierającego się na własności socjalistycznej państwa. $\mathrm{W}$ związku z tym również polskie regulacje $\mathrm{w}$ zakresie postępowania cywilnego miały służyć ochronie przede wszystkim interesów państwowych instytucji, organizacji społecznych, przedsiębiorstw państwowych, spółdzielni, a w mniejszym zakresie interesów obywateli. Jak bowiem wypowiadano się wówczas w literaturze przedmiotu:

postępowanie cywilne powinno również sprzyjać umocnieniu socjalistycznej praworządności, zapobiegać naruszeniom prawa oraz wychowywać obywateli w duchu przestrzegania ustaw oraz zasad współżycia socjalistycznego ${ }^{8}$.

Wśród funkcji postępowania cywilnego podkreślano zatem funkcję wychowawczą, ale w zakresie przestrzegania prawa socjalistycznego nakierunkowanego na ochronę własności państwowej i spółdzielczej w celu realizacji

planu budownictwa komunistycznego, którego urzeczywistnienie wymaga podniesienia poziomu świadomości mas, uformowania osobowości człowieka w duchu kolektywizmu i zamiłowania do pracy, uświadomienia obowiązków społecznych i przestrzegania zasad moralnych nowego społeczeństwa9 .

Jak to wówczas określono, ,nowy ład społeczny” miał być urzeczywistniany między innymi za pomocą instrumentów prawnoprocesowych, w tym regulacji dotyczących postępowania cywilnego, aby mieć możliwość ingerencji władczej w sferę prywatną obywateli w celu kształtowania socjalistycznych, a więc „właściwych postaw społecznych" w okresie reżimu państwa totalitarnego. Do instrumentów prawnych mających zapewnić realizację tych celów zaliczano: możliwość uczestniczenia w postępowaniu cywilnym również organizacji społecznych, badanie i uogólnianie praktyki orzeczniczej poprzez władczy nadzór nad sądami przez Sąd Najwyższy, w istocie tworzący wiążące ogólne zasady prawne, przesyłanie odpisów orzeczeń organom władzy państwowej i państwowym instytucjom prawnym, a także przeprowadzanie procesów w zainteresowanych środowiskach (państwowy arbitraż gospodarczy).

Jak z tego wynika, rola postępowania cywilnego w okresie socjalistycznych regulacji prawnych w PRL znacznie wzrosła, albowiem celem tego postępowania nie było tylko rozpoznanie sprawy, lecz zastosowanie do ustalonego stanu faktycznego właściwej normy prawa materialnego. Funkcja postępowania cywilnego przejawiała się w kształtowaniu norm społecznych i moralnych, aby doprowadzić do przeobrażenia społeczeństwa burżuazyjnego w socjalistyczne poprzez kształtowanie ,światopoglądu socjalistycznego”. W związku z tym postępowanie

\footnotetext{
8 Ibidem, s. 71.
}

9 Ibidem, s. 72. 
cywilne miało służyć zapobieganiu naruszeniom prawa nie tylko w przypadku, kiedy jednostka uzna za konieczne ochronę swoich praw, ale też kiedy do takiego naruszenia prawa dochodzi, a jednostka nie podejmuje czynności w celu realizacji ochrony swoich praw. W związku z tym nie tylko dopuszczono możliwość inicjowania i prowadzenia postępowania cywilnego przez prokuratora, który niejako $\mathrm{z}$ racji pełnionych funkcji podejmuje czynności w celu przestrzegania praworządności, lecz także prawo to przyznano organizacjom społecznym oraz innym instytucjom (w tym inspektorom pracy oraz innych państwowych jednostek).

O ile zrozumiała jest możliwość inicjowania postępowania oraz udział w postępowaniu przez prokuratora $\mathrm{w}$ celu zapewnienia praworządności, o tyle niezrozumiałe jest ingerowanie $\mathrm{w}$ sferę praw jednostki poprzez inicjowanie postępowania cywilnego bez jej woli lub nawet wbrew jej woli. Tego rodzaju sposób prowadzenia postępowania jest bowiem charakterystyczny dla spraw rozpoznawanych w postępowaniu administracyjnym. Sprawy administracyjne, w przeciwieństwie do cywilnych, nie wiążą się wszak z równoprawnym traktowaniem stron postępowania, a umożliwiają stosowanie środków przymusu państwowego. W orzecznictwie wyrażano jednak wówczas stanowisko, że

Jeżeli w sprawach o zaprzeczenie pochodzenia dziecka i unieważnienie uznania (art. 86 k.p.c.) powództwo wytoczył prokurator, to może on samodzielnie rozporządzać przedmiotem sporu w tym sensie, że może dokonać cofnięcia powództwa, jak i cofnąć powództwo ze zrzeczeniem się „roszczenia”. W takiej sytuacji rozporządzenie procesem i jego przedmiotem nie podlega kontroli ze strony sądu (art. 203 par. 4 k.p.c.), a zezwolenie na cofnięcie powództwa lub brak tego zezwolenia (art. $454 \S 2$ i 3 k.p.c.) nie pociąga za sobą skutków przewidzianych w art. 203 $\S 1$ k.p.c. $)^{10}$.

Prokurator miał zatem wówczas pełną autonomię w odniesieniu do czynności podejmowanych w toku postępowania cywilnego.

Do dziś obowiązują niektóre regulacje pozwalające na ingerencję w sferę prawną strony procesu cywilnego czy uczestnika postępowania nieprocesowego. Przede wszystkim pozostawiono możliwość zainicjowania przez państwowego inspektora pracy postępowania o ustalenie istnienia lub nieistnienia stosunku pracy. Dalsze obowiązywanie takich regulacji pozwala na stymulacyjne działanie przez organy państwa na sfery prawne obywateli w zakresie, w którym takiego rodzaju ingerencja może być konieczna.

$\mathrm{Z}$ opisanymi funkcjami ściśle wiązały się obowiązujące w okresie PRL zasady postępowania cywilnego, stanowiące idee przewodnie dla organów prowadzących postępowanie, obrazujące ideologię tamtego okresu. Poszczególne zasady procesowe były bowiem powiązane $\mathrm{z}$ celami i funkcjami procesu cywilnego. Naczelne zasady procesowe nie tylko miały na celu zapewnienie sprawnego przeprowadzenia postępowania $\mathrm{w}$ danej sprawie, ale miały umożliwiać organowi

10 Postanowienie Sądu Najwyższego — Izba Cywilna z dnia 20 grudnia 1973 roku, sygn. II CR 211/73, Legalis. 
kierowanie przebiegiem postępowania. W związku z tym już wówczas obowiązywały zasady kierownictwa sędziowskiego i koncentracji materiału procesowego, zasada bezpośredniości, ustności i swobodnej oceny dowodów, choć odmiennie niż obecnie były one rozumiane i stosowane. W okresie socjalistycznym państwa polskiego zasada prawdy obiektywnej oraz zasada inicjatywy sądu ${ }^{11}$ miały bowiem służyć realizacji i zapewnieniu ochrony interesów społecznych ${ }^{12}$. W ówczesnej literaturze przedmiotu podkreślano, że pełniła ona wielorakie funkcje w całym mechanizmie państwa socjalistycznego, a w marksistowskiej teorii poznania uwagę poświęca się zagadnieniu prawdy obiektywnej, która

oznacza wierność i adekwatność odzwierciedlenia w ustaleniach sądu określonego wycinka społecznej rzeczywistości, co do którego zachodzi potrzeba zastosowania przez sąd pewnej normy prawnej, a więc prawdziwość wiedzy o faktach, składających się na wycinek rzeczywistości i wiedzy o zależnościach przyczynowych między tymi faktami ${ }^{13}$.

Zasada inicjatywy sądu była przeciwstawiana zasadzie autonomii, która jak podkreślano - była charakterystyczna dla okresu burżuazyjnego.

W ustroju socjalistycznym, w którym istotne znaczenie miała rola wychowawcza postępowania sądowego, a rozstrzyganie spraw cywilnych było jednym z ogniw w łańcuchu środków kształtowania nowych stosunków międzyludzkich, podkreślano, że tok postępowania cywilnego nie może być uzależniony od woli stron $^{14}$. Zaprezentowany pogląd potwierdza ówczesne podejście do roli państwa oraz systemu sądowniczego, który był podporządkowany ideom wychowawczej roli państwa i wpływu na stosunki międzyludzkie nie tylko w sferze publicznoprawnej. W związku z tym regulacje prawne miały zapewnić możliwe władcze ingerowanie w tok prowadzonego postępowania cywilnego niezależnie od woli stron. W judykaturze wyrażono stanowisko, że

umorzenie postępowania w sprawie z przyczyny cofnięcia pozwu bez jakiejkolwiek ze strony sądu oceny tej dyspozycji strony pod kątem jej zgodności z prawem lub zasadami współżycia

11 Od tej zasady działania sądu z urzędu odstąpiono w związku z wejściem w życie ustawy o zmianie kodeksu postępowania cywilnego, rozporządzeń Prezydenta Rzeczypospolitej — prawo upadłościowe i prawo o postępowaniu układowym, kodeksu postępowania administracyjnego, ustawy o kosztach sądowych w sprawach cywilnych z dnia 1 marca 1996 roku (Dz.U. Nr 43, poz. 189). Mimo to w judykaturze nawet po wejściu w życie zmian wyrażano stanowisko, że „Wynikające z tej nowelizacji ograniczenie obowiązku działania sądu z urzędu i przesunięcie ciężaru dowodzenia na same strony (zasady kontradyktoryjności i dyspozycyjności), przejawiające się w szczególności w nowym brzmieniu art. 3, 203, 213, 232 i 316 k.p.c., nie zwalnia sądu z obowiązku działania z urzędu z dwóch przyczyn: 1) sąd ma obecnie prawo, a nie obowiązek działania z urzędu, 2) powinien jednak takie działanie podjąć, gdy obowiązek ten wynika z wyraźnego unormowania kodeksu, bądź w sprawie zostały ujawnione środki dowodowe istotne dla rozstrzygnięcia sprawy. Do takiego unormowania należą zaś m.in. niektóre przepisy dotyczące postępowania odrębnego w sprawach małżeńskich (art. 425-458 k.p.c.)" — uzasadnienie postanowienia Sądu Najwyższego — Izba Cywilna z dnia 5 lutego 1997 roku, sygn. I CKU 81/96, Legalis.

12 Por. W. Broniewicz, op. cit., s. 231 i 238.

13 Ibidem, s. 232.

14 Ibidem, s. 236. 
społecznego albo czy nie narusza to rażąco jej interesu, jest naruszeniem art. $203 \S 4 \mathrm{w}$ związku z art. $355 \S 1$ k.p.c. ${ }^{15}$

Szczególnej ochronie podlegała własność społeczna nie tylko na etapie postępowań sądowych, ale też w regulacjach odnoszących się do jednostek gospodarki uspołecznionej. Dlatego też Sąd Najwyższy wyraził wówczas pogląd, że

Obowiązek ochrony własności społecznej ciąży przede wszystkim na przedmiotach bezpośrednio odpowiedzialnych za powierzone ich pieczy mienie, a powinność sądu w tym zakresie nie może być rozumiana $w$ ten sposób, aby musiał on wyręczyć jednostki gospodarki uspołecznionej - powinien ingerować dopiero wtedy, gdy okoliczności sprawy nasuwają w tym względzie uzasadnione obawy. Nie można więc czynić zasadnie sądowi zarzutu niedołożenia należytej staranności przy kontroli ugody sądowej, jeżeli nie sprzeciwiał się jej zawarciu w sytuacji, gdy jednostka gospodarki uspołecznionej była reprezentowana przez radcę prawnego, wartość przedmiotu ugody została określona przez biegłego, a okoliczności sprawy nie nasuwały zastrzeżeń co do prawidłowego wykonywania swych obowiązków przez przedstawiciela strony i rzetelności opinii rzeczoznawcy ${ }^{16}$.

W obecnym stanie prawnym także pozostawione zostały regulacje prawne umożliwiające ocenę czynności dyspozycyjnych stron w postępowaniu cywilnym, ale ma to charakter wyjątkowy. Przykładowo przepis art. $203 \S 4$ k.p.c. stanowi, że sąd wprawdzie może uznać za niedopuszczalne cofnięcie pozwu, zrzeczenie się lub ograniczenie roszczenia, ale tylko wtedy, gdy okoliczności sprawy wskazują, że wymienione czynności są sprzeczne z prawem lub zasadami współżycia społecznego albo zmierzają do obejścia prawa.

Jako zasadę wskazywano także zapewnienie ochrony własności społecznej jako „głównej podstawy kraju i pomyślności narodu” (art. 5 pkt 4 Konstytucji PRL z 22 lipca 1952, Dz.U. z $1952 \mathrm{Nr} 33$, poz. 232). Zasada ta wymagała ze strony organów prowadzących postępowanie cywilne zapewnienia należytej ochrony prawnoprocesowej $\mathrm{w}$ wypadku, kiedy stroną lub uczestnikiem postępowania była jednostka gospodarki uspołecznionej (dalej: j.g.u.). W myśl art. 4 k.p.c. z 1964 roku sąd miał obowiązek dążyć do zapewnienia należytej ochrony własności społecznej. Przepisy kodeksu postępowania cywilnego termin j.g.u. odnosiły do Skarbu Państwa, innych państwowych jednostek organizacyjnych oraz innych jednostek gospodarki uspołecznionej, a więc bardzo szeroko, odwołując się do przepisów prawa materialnego ${ }^{17}$. Ponadto przepisy kodeksu odnoszące się do j.g.u. należało odpowiednio stosować także do instytucji państwowych, których zadania nie polegały na prowadzeniu działalności gospodarczej (art. 14 k.p.c. z 1964 roku $^{18}$ ).

15 Postanowienie Sądu Najwyższego — Izba Cywilna z dnia 23 lipca 1970 roku, sygn. II CZ 91/70, Legalis.

16 Postanowienie Sądu Najwyższego — Izba Cywilna z dnia 28 marca 1974 roku, sygn. III CRN 13/74, Legalis.

17 Komentarz do kodeksu postępowania cywilnego, t. 1, red. Z. Resich, W. Siedlecki, Warszawa 1975-1976, s. $92 \mathrm{n}$.

18 Przepis art. 14 został uchylony na mocy art. 1 pkt 4 ustawy o kosztach sądowych w sprawach cywilnych z dnia 1 marca 1996 roku (Dz.U. Nr 43, poz. 189). 
Natomiast do zasad realizacji ochrony interesów indywidualnych w okresie PRL zaliczano zasady równości stron, dyspozycyjności oraz kontradyktoryjności, choć podkreślano znaczenie aktywnej roli prokuratora i organizacji społecznych jako podmiotów działających na prawach strony. W okresie PRL łączono funkcję ochronną państwa $\mathrm{z}$ ochroną interesu jednostki. Postępowanie cywilne $\mathrm{w}$ ustroju socjalistycznym nie tylko miało zapewnić poszanowanie prawa $\mathrm{w}$ społeczeństwie, ale też stwarzać podstawy do uporządkowania życia gospodarczego i społecznego. Podkreślano, że

z podstawowej zgodności interesów społecznych i indywidualnych w ustroju socjalistycznym wynika, że nieudzielenie ochrony słusznym interesom jednostki, w razie ich naruszenia lub zagrożenia, godzi również w interesy społeczne. Dlatego organy, które w ustroju socjalistycznym są powołane do strzeżenia tych interesów, muszą mieć prawo i obowiązek działania nie tylko przy bezpośrednim ich naruszeniu, ale także pośrednim — poprzez naruszenie interesów indywidualnych ${ }^{19}$.

W związku z tym w postępowaniu cywilnym w okresie socjalistycznym w Polsce wola osób bezpośrednio zainteresowanych zainicjowaniem i prowadzeniem postępowania cywilnego w pewnym sensie była stymulowana przez organy stojące na straży praworządnego państwa socjalistycznego, co przejawiało się wprost w regulacji przepisu art. 7 k.p.c., który w pierwotnie uchwalonym brzmieniu stanowił, że

Prokurator może żądać wszczęcia postępowania w każdej sprawie, jak również wziąć udział w każdym toczącym się już postępowaniu, jeżeli według jego oceny wymaga tego ochrona praworządności, praw obywateli, interesu społecznego lub własności społecznej. W sprawach niemajątkowych z zakresu prawa rodzinnego prokurator może wytaczać powództwa tylko w wypadkach wskazanych w ustawie ${ }^{20}$.

\section{Ówcześnie w podręcznikach do postępowania cywilnego podkreślano, że}

Postępowanie cywilne spełnia doniosłą rolę społeczną. Interes społeczny bowiem wymaga, by normy prawne będące wyrazem woli klasy rządzącej w państwie były stosowane, a w wypadku ich niestosowania, by nastąpiło przymusowe ich urzeczywistnienie. Instytucja postępowania cywilnego nie tylko zapewnia poszanowanie prawa w społeczeństwie, ale także stwarza podstawy do uporządkowania życia gospodarczego i społecznego ${ }^{21}$.

Wielopłaszczyznowość funkcji, jaką miały pełnić regulacje dotyczące postępowania cywilnego, można podsumować stwierdzeniem Włodzimierza Berutowicza, że

funkcję postępowania cywilnego w PRL stanowi ta część wymiaru sprawiedliwości jako przejawu funkcji wewnętrznej państwa, która obejmuje ochronę socjalistycznego porządku prawnego i sfery prawnej jednostek w zakresie stosunków cywilnych, rodzinnych i pracy, przez konkrety-

19 W. Broniewicz, op. cit., s. 242.

20 Przepis art. 7 k.p.c. został zmieniony na mocy art. 1 pkt 2 ustawy o zmianie ustawy — kodeks postępowania cywilnego z dnia 13 lipca 1990 roku (Dz.U. Nr 55, poz. 318) poprzez skreślenie „własności społecznej”.

21 W. Siedlecki, op. cit., s. 11. 
zowanie i przymusowe urzeczywistnianie w tym zakresie norm prawnych, a także wychowawcze oddziaływanie na obywateli, aby swoje stosunki i interesy prawne kształtowali, dobrowolnie i świadomie, zgodnie z przepisami prawnymi obowiązującymi w poszczególnych dziedzinach ${ }^{22}$.

Reasumując, należy wskazać, że totalitaryzm okresu socjalistycznego w PRL spowodował, że zasady postępowania cywilnego uległy modyfikacji, w celu ich dostosowania do umacniania socjalistycznej praworządności, zapobiegania naruszeniom prawa, ale w aspekcie przede wszystkim ochrony własności społecznej i państwowej. Przedstawione historyczne regulacje prawne potwierdzają, że na wykładnię oraz zasady postępowania cywilnego istotny wpływ mają obowiązujące $\mathrm{w}$ danym momencie regulacje prawne, na które oddziałuje także ustrój polityczny państwa, albowiem - jak już wtedy dostrzegano - funkcja postępowania cywilnego wchodzi w zakres zasadniczych funkcji państwa ${ }^{23}$.

\section{Bibliografia}

\section{Literatura}

Berutowicz W., Funkcja postepowania cywilnego w Polsce Ludowej, [w:] Wstep do systemu prawa procesowego cywilnego. Zbiór studiów, red. J. Jodłowski, Wrocław-Warszawa-Kraków-Gdańsk 1974.

Broniewicz W., Postepowanie cywilne, Warszawa 1978.

Komentarz do kodeksu postępowania cywilnego, t. 1, red. Z. Resich, W. Siedlecki, Warszawa 19751976.

Siedlecki W., Postepowanie cywilne. Zarys wykładu, Warszawa 1977.

Włodyka S., Ustrój organów ochrony prawnej, Warszawa 1975.

\section{Orzecznictwo}

Postanowienie Sądu Najwyższego — Izba Cywilna z dnia 23 lipca 1970 roku, sygn. II CZ 91/70, Legalis.

Postanowienie Sądu Najwyższego — Izba Cywilna z dnia 20 grudnia 1973 roku, sygn. II CR 211/73, Legalis.

Postanowienie Sądu Najwyższego — Izba Cywilna z dnia 28 marca 1974 roku, sygn. III CRN 13/74, Legalis.

Postanowienie Sądu Najwyższego — Izba Cywilna z dnia 5 lutego 1997 roku, sygn. I CKU 81/96, Legalis.

22 Ibidem, s. 84.

23 Ibidem, s. 11. 